\title{
A CLADISTIC ANALYSIS OF $n d h F$ SEQUENCES FROM REPRESENTATIVE SPECIES OF SAINTPAULIA AND STREPTOCARPUS SUBGENERA STREPTOCARPUS AND STREPTOCARPELLA (GESNERIACEAE)
}

\author{
J. F. SMITH*, M. E. KRESGE*, M. MÖLLER† \& \\ Q. C. B. CRONK $+\ddagger$
}

\begin{abstract}
Two African genera of the Gesneriaceae, Saintpaulia and Streptocarpus, are similar in many respects. Both genera have blue to purple flowers, pollen of similar shape and exine sculpting, embryos with one-celled, uninucleate chalazal haustoria, shared vegetative structures among some species, and are among the few genera in the Gesneriaceae which include species with chromosome counts of $n=15$. The similarity of these features has indicated that the two genera are likely to be closely related. This study examines the sequences of the chloroplast gene $n d h \mathrm{~F}$ among several representative species of Saintpaulia and representatives of Streptocarpus subgenera Streptocarpella and Streptocarpus. The results of this analysis are congruent with those of a previous analysis based on the nuclear ribosomal region, ITS. Saintpaulia was found to be nested within Streptocarpus subgenus Streptocarpella. The results raise the possibility of the taxonomic revision of these genera, and this is discussed.

Comparisons between the data sets are made regarding utility of the two regions, sample size and outgroup.
\end{abstract}

Keywords. African violet, Cape primrose, cladistic analysis, $n d h \mathrm{~F}$.

\section{INTRODUCTION}

The majority of species in the Old World subfamily of Gesneriaceae, Cyrtandroideae, are distributed in south-east Asia and China with a few genera in Africa and Europe (Wang et al., 1992; Burtt \& Wiehler, 1995). Among the African genera are the widely cultivated African violet (Saintpaulia Wendl.) and the Cape primrose (Streptocarpus Lindl.). These two genera have been thought to be closely related on the basis of numerous characters. Among these are shared pollen shape and exine sculpting (Weigend \& Edwards, 1996), one-celled, uninucleate chalazal haustoria in embryos (Holmqvist, 1964), rosulate herbs with orbicular, petiolate leaves common to Saintpaulia and some species of Streptocarpus (Hilliard \& Burtt, 1971) and (in subg. Streptocarpella) chromosome counts of $n=15$ (Skog, 1984) (although Streptocarpus subg. Streptocarpus has $n=16$ ).

\footnotetext{
* Biology Department, Boise State University, 1910 University Drive, Boise, Idaho 83725, USA.

† Royal Botanic Garden Edinburgh, 20A Inverleith Row, Edinburgh EH3 5LR, UK.

$\ddagger$ Institute of Cell and Molecular Biology, The University of Edinburgh, Kings Buildings, Mayfield Road, Edinburgh EH9 3JH, UK.
} 
Early interpretations of relationships among African genera of the Gesneriaceae indicated neither unity nor a strong relationship between Saintpaulia and Streptocarpus. However, as additional species were described and the characters of the African Gesneriaceae examined more carefully, a closer relationship among all of the African genera of Gesneriaceae, in particular Saintpaulia and Streptocarpus, became apparent (Hilliard \& Burtt, 1971).

Saintpaulia and Streptocarpus have a similar embryology (Holmqvist, 1964). In these two genera the chalazal haustorium is always one-celled and uninucleate, degenerating very quickly (Holmqvist, 1964). In Asiatic genera (Boea Comm. ex Lam. and Chirita Ham ex G. Don) the haustorium is large, unicellular and binucleate (Holmqvist, 1964).

Both Saintpaulia and Streptocarpus have similar pollen structure. The pollen of all African species examined was found to be eurypalynous, prolate to spheroidal to oblate, triporate or tricolpate to tricolporate, and the colpus margin is not differentiated (Weigend \& Edwards, 1996). The similarity of the pollen more than likely reflects a monophyletic lineage of all African genera (Weigend \& Edwards, 1996). Additionally, some Streptocarpus species share similar pollen types to Saintpaulia although exact relationships between these genera cannot be made with pollen data alone (Weigend \& Edwards, 1996).

A cladistic analysis of the tribes of the Gesneriaceae based on morphological data included both Saintpaulia and Streptocarpus (Smith, 1996). A strict consensus of the trees from this analysis placed both genera in a polytomy, although the majority of trees placed Streptocarpus as the sister to Ornithoboea Parish ex C.B. Clarke on the basis of twisted carpels common to these two genera. In a similar analysis, based on comparison of $n d h \mathrm{~F}$ sequences, Smith et al. (1997a) found that the single species of Saintpaulia included was the sister to Streptocarpus holstii. Streptocarpus saxorum was the sister to both of these two species. Thus, Saintpaulia was nested within Streptocarpus.

The close relationship of Saintpaulia and Streptocarpus based on the above data prompted further investigations using the chloroplast DNA (cpDNA) encoded $n d h \mathrm{~F}$ gene, the results of which are presented in this paper. Möller \& Cronk (1997) examined the relationship of Saintpaulia to the subgenera and sections of Streptocarpus using the nuclear ribosomal DNA (nrDNA) ITS region. They concluded that Saintpaulia was nested within Streptocarpus subg. Streptocarpella Fritsch and resolved relationships among other sections of Streptocarpus (Möller \& Cronk, 1997).

The present paper presents a cladistic analysis of the cpDNA data and makes comparisons with the results of Möller \& Cronk (1997). This paper examines a much more thorough sampling of Saintpaulia and Streptocarpus with the $n d h \mathrm{~F}$ gene than has been examined previously (Smith et al., 1997a).

The source of molecular data for this analysis is the chloroplast DNA encoded gene $n d h \mathrm{~F}$ which in tobacco encodes a protein of 740 amino acids presumed to be a subunit of an NADH dehydrogenase (Sugiura, 1992). The use of $n d h \mathrm{~F}$ sequences 
for systematic studies has provided a far greater number of characters to resolve relationships than studies using $r b c \mathrm{~L}$ (Olmstead \& Sweere, 1994; Clark et al., 1995; Olmstead \& Reeves, 1995; Scotland et al., 1995; Smith et al., 1997a, b). In general, the $n d h \mathrm{~F}$ gene is $50 \%$ larger than $r b c \mathrm{~L}$ and has a nucleotide substitution rate approximately two times higher (Sugiura, 1989). The larger number of variable characters makes $n d h \mathrm{~F}$ sequences ideal for taxonomic groups that have not been resolved well using $r b c \mathrm{~L}$ data, such as members of the Asteridae and Lamiales s.l. (Olmstead et al., 1992, 1993; Chase et al., 1993).

\section{MATERIALS AND METHODS}

The gene sequences used in this analysis were generated by thermal cycle sequencing (Innis et al., 1988) of previously amplified $n d h \mathrm{~F}$ regions. The $n d h \mathrm{~F}$ gene was amplified in two overlapping sections (positions 1-1350, and 972-2044) from genomic DNA isolated from fresh or frozen material (Smith et al., 1992). Amplification and sequencing procedures followed that of Smith et al. (1997a) used for other members of the Gesneriaceae. The species used in the analysis, voucher information, and Genbank accession numbers are shown in Table 1. Outgroups included two members of the Buddlejaceae, selected on the basis of recent molecular analyses that indicate the Buddlejaceae to be the sister to the Gesneriaceae (Smith et al., 1997b). Other members of the Old World subfamily Cyrtandroideae were included in this analysis to verify that neither Streptocarpus nor Saintpaulia had any affinities with other genera.

Phylogenetic trees were reconstructed using PAUP (Phylogenetic Analysis Using Parsimony) version 3.1.1 (Swofford, 1993) to implement parsimony (Farris, 1970; Farris et al., 1970; Swofford \& Maddison, 1987). In this analysis, trees were generated using the general heuristic option, saving minimal trees only, with the collapse zerolength branches, and ignore uninformative characters options in effect. Because of the large number of taxa in this analysis, the branch and bound and exhaustive search options would have consumed an excessive amount of time. Therefore, the trees presented here are best approximations and not exact solutions. The manner in which the program reconstructs phylogenetic sequences is sensitive to the order of taxa presentation in the data matrix, frequently finding islands of equally parsimonious trees depending on the order (Maddison, 1991). Therefore, it is important to repeat the analysis several times, each time with a different starting place in the data matrix. To do this, the search strategy of Olmstead \& Palmer (1994) was implemented searching for 1000 trees each using the 'random addition sequence' in five subsequent analyses with the nearest neighbour interchange (NNI) search option in effect and mulpars 'off'. Each of the results from the five NNI searches was used as the starting tree(s) for a search with tree bisection reconnection (TBR) and mulpars 'on'. The mulpars option, when 'on', will save all equally parsimonious trees.

Branch support analysis was performed to examine trees that were three or fewer steps longer than the most-parsimonious tree (Bremer, 1988, 1994; Donoghue et al., 1992). This type of analysis provides an indication of the robustness of the data by 
TA BLE 1. Species sequenced in this study with Genbank submission numbers and voucher specimens. SI, Smithsonian Institution. Letters in parentheses indicate herbarium where vouchers are deposited.

\begin{tabular}{|c|c|c|}
\hline Species & Voucher & $\begin{array}{l}\text { Genbank } \\
\text { Number }\end{array}$ \\
\hline Aeschynanthus micranthus C.B. Clarke & Smith et al. $1997 \mathrm{a}$ & U62169 \\
\hline Agalmyla parasitica (Lam.) Kuntze & Smith et al. 1997a & U62171 \\
\hline $\begin{array}{l}\text { Anna mollifolia (W.T. Wang) W.T. Wang \& } \\
\text { K.Y. Pan }\end{array}$ & Smith et al. $1997 \mathrm{a}$ & U62188 \\
\hline Boea hygroscopica F. Muell. & Smith et al. 1997 a & U62205 \\
\hline Chirita sinensis Lindl. & Smith et al. 1997a & U62189 \\
\hline Cyrtandra hawaiensis C.B. Clarke & Smith et al. 1997a & $\mathrm{U} 62172$ \\
\hline Cyrtandra umbellifera Merr. & Smith et al. $1997 \mathrm{a}$ & U62165 \\
\hline Cyrtandromoea acuminata Benth. \& Hook. & Smith et al. $1997 \mathrm{a}$ & U62173 \\
\hline Didissandra frutescens Clarke & Smith et al. $1997 \mathrm{a}$ & U62190 \\
\hline Didymocarpus albomarginata Hemsl. & Smith et al. 1997 a & U62207 \\
\hline Hemiboea henryi C.B. Clarke & Smith et al. 1997a & U62180 \\
\hline Lysionotus pauciflorus Maxim. & Smith et al. 1997 a & U62182 \\
\hline Monophyllaea hirticalyx Franch. & Smith et al. $1997 \mathrm{a}$ & U62168 \\
\hline Opithandra primuloides (Miq.) B.L. Burtt & Smith et al. 1997a & U62183 \\
\hline Ornithoboea wildeana Craib. & Smith et al. 1997a & U62166 \\
\hline Paraboea rufescens (Franch.) Burtt & Smith et al. $1997 \mathrm{a}$ & U62206 \\
\hline Petrocosmea flaccida Craib & Smith et al. $1997 \mathrm{a}$ & U62184 \\
\hline Primulina tabacum Hance & Smith et al. 1997a & U62167 \\
\hline Ramonda myconi (L.) Rchb. & Smith et al. $1997 \mathrm{a}$ & U62185 \\
\hline Rhynchoglossum notonianum (Wall.) B.L. Burtt & Smith et al. $1997 \mathrm{a}$ & U62179 \\
\hline Saintpaulia difficilis B.L. Burtt & Smith 3602 (SRP) & AFO12837 \\
\hline S. diplotricha B.L. Burtt & Smith 3601 (SRP) & AFO12838 \\
\hline S. grotei Engl. & Smith 3598 (SRP) & AFO12839 \\
\hline S. grandifolia B.L. Burtt & Smith 3702 (SRP) & AFO12840 \\
\hline S. pendula B.L. Burtt & no voucher & AFO12841 \\
\hline S. rupicola B.L. Burtt & Smith et al. $1997 \mathrm{a}$ & U62176 \\
\hline Streptocarpus cyaneus S. Moore & SI $94-596$ & AFO12843 \\
\hline S. fanniniae Harvey ex C.B. Clarke & SI 94-137 & AFO12844 \\
\hline S. holstii Engl. & Olmstead \& Reeves 1995 & L36415 \\
\hline S. johannis L.L. Britten & SI $94-223$ & AFO12845 \\
\hline S. porphyrostachys Hilliard & SI 94-141 & AFO12846 \\
\hline S. primulifolius Gandoger & SI $94-096$ & AFO12847 \\
\hline S. saxorum Engl. & Smith et al. $1997 \mathrm{a}$ & U62170 \\
\hline$S . \mathrm{sp}$ & SI $94-500$ & AFO12849 \\
\hline S. vandeleurii E.G. Baker \& S. Moore & SI $95-130$ & AFO1 2848 \\
\hline Titanotrichum oldhamii (Hemsl.) Soler. & Smith et al. $1997 \mathrm{a}$ & U62187 \\
\hline \multicolumn{3}{|l|}{ Outgroups } \\
\hline Buddleja davidii Franch. & Olmstead \& Reeves 1995 & L36394 \\
\hline Nicodemia diversifolia (Vahl.) Ren. & Olmstead \& Reeves 1995 & L36405 \\
\hline
\end{tabular}


determining which clades persist in a consensus tree as parsimony is relaxed. This analysis was performed by saving all trees three steps longer than the mostparsimonious trees and then examining subsets of trees one to three steps longer with the filter option of PAUP.

Bootstrap analysis (Felsenstein, 1985) was performed using 1000 replicates. An estimate of how well the data fit the tree was determined by calculating the $\mathrm{g}_{1}$ statistic (Hillis \& Huelsenbeck, 1992) using 10,000 random trees.

\section{RESULTS}

A total of 2223 base pairs of $n d h \mathrm{~F}$ were sequenced for each species in this analysis. Of these base pairs, 408 were variable and phylogenetically informative among the species used in this analysis (Table 1). An insertion at position 1440 of 13 base pairs was found in all species examined. The sequence of this insertion was not used in the cladistic analysis. Only two base pairs differ among all of the species of Saintpaulia and Streptocarpus included in this analysis, therefore the choice to exclude this insertion (due to possible lack of homology) is not likely to have altered the results.

The cladistic analysis of $n d h \mathrm{~F}$ sequences resulted in 253 trees of 2904 steps each, consistency index $(\mathrm{CI})=0.31$, retention index $(\mathrm{RI})=0.38$. The strict consensus of these trees is presented in Fig. 1. Saintpaulia and Streptocarpus form a monophyletic group. However, neither Saintpaulia nor Streptocarpus are monophyletic. The Saintpaulia species are in a polytomy with the two species of Streptocarpus subg. Streptocarpella (Fig. 1). There is significantly more structure than random data within this analysis as reflected by the $\mathrm{g}_{1}$ statistic $(-0.392)$. Extrapolation from the charts generated by Hillis \& Huelsenbeck (1992) for the number of characters and taxa used in this analysis indicates that the $\mathrm{g}_{1}$ is clearly significant at $P<0.01$.

The general results of this analysis are found to be completely congruent with those of Möller \& Cronk (1997) based on ITS sequences. Because the sampling between the two studies was not identical, this study does not resolve relationships among the different sections of Streptocarpus and in general provides less resolution among the included taxa than does the ITS region.

\section{DISCUSSION}

Cladistic analysis of the cpDNA gene $n d h \mathrm{~F}$ indicates that Saintpaulia is closely related to Streptocarpus subg. Streptocarpella (Fig. 1). Poor resolution of the relationship between Saintpaulia and Streptocarpus subg. Streptocarpella prevents further speculation on the exact relationship between these two taxa. For example, Saintpaulia could be a monophyletic group that is a sister to subg. Streptocarpella, or be paraphyletic. Regardless, the data provide evidence that Saintpaulia is derived from within Streptocarpus and in particular shows a close affinity to subg. Streptocarpella (Fig. 1).

Further evidence for the relationship of Saintpaulia to Streptocarpus subg. 


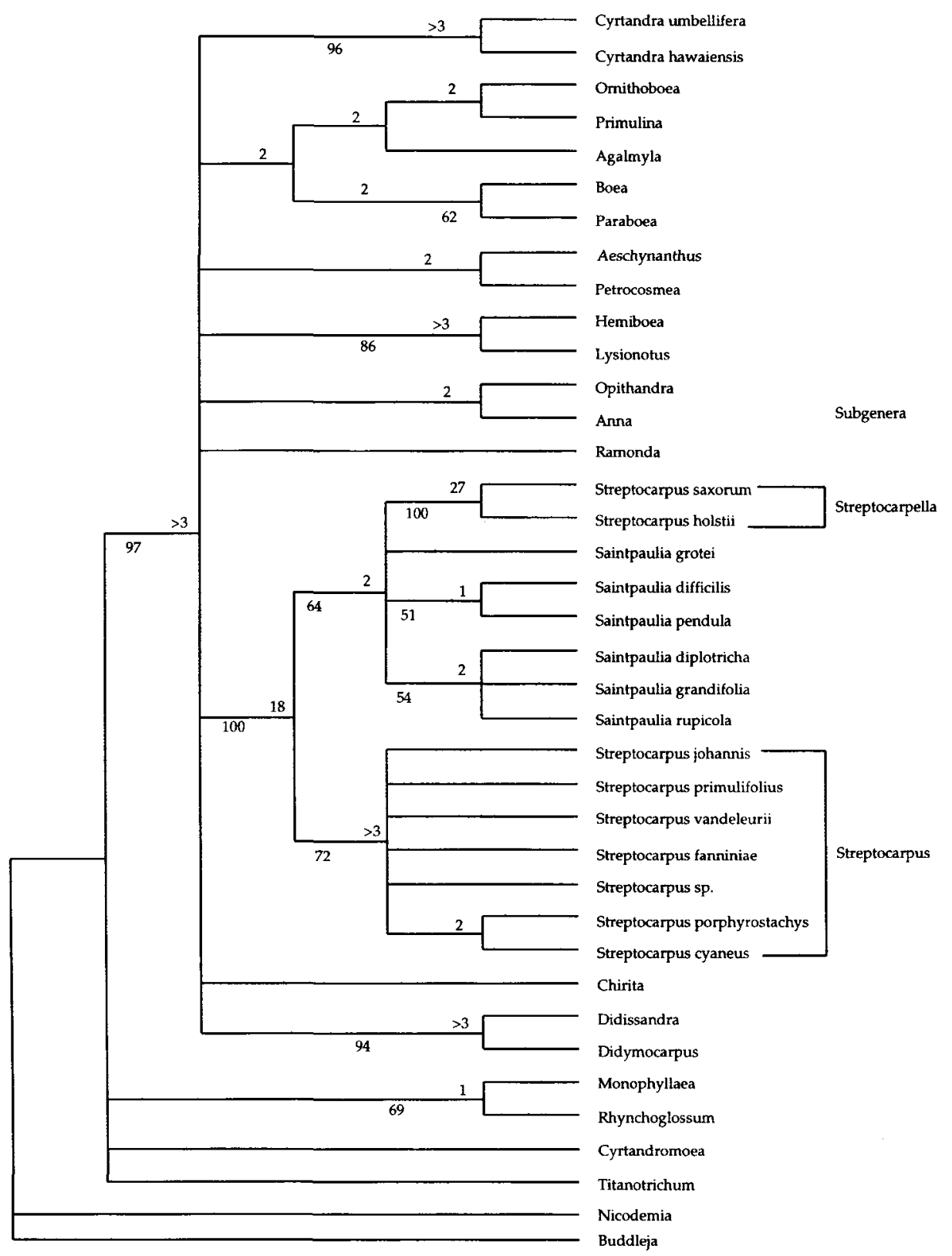

FIG. 1. Strict consensus of 253 trees of 2904 steps each $(C I=0.31, R I=0.38)$ based on cpDNA $n d h \mathrm{~F}$ gene sequences. Numbers above clades are decay values, numbers below clades are bootstrap values. Subgenera of Streptocarpus are indicated on the figure. 
Streptocarpella comes from ITS sequence data (Möller \& Cronk, 1997). The results from the ITS sequencing are congruent with the results of the $n d h \mathrm{~F}$ sequencing presented here with the benefit of higher resolution among the species examined (Fig. 2; Möller \& Cronk, 1997). The ITS data places Saintpaulia as a monophyletic group nested within subg. Streptocarpella (Fig. 2).

Lastly, the close relationship between Saintpaulia and subg. Streptocarpella is supported by data from pollen analysis (Weigend \& Edwards, 1996) and chromo-

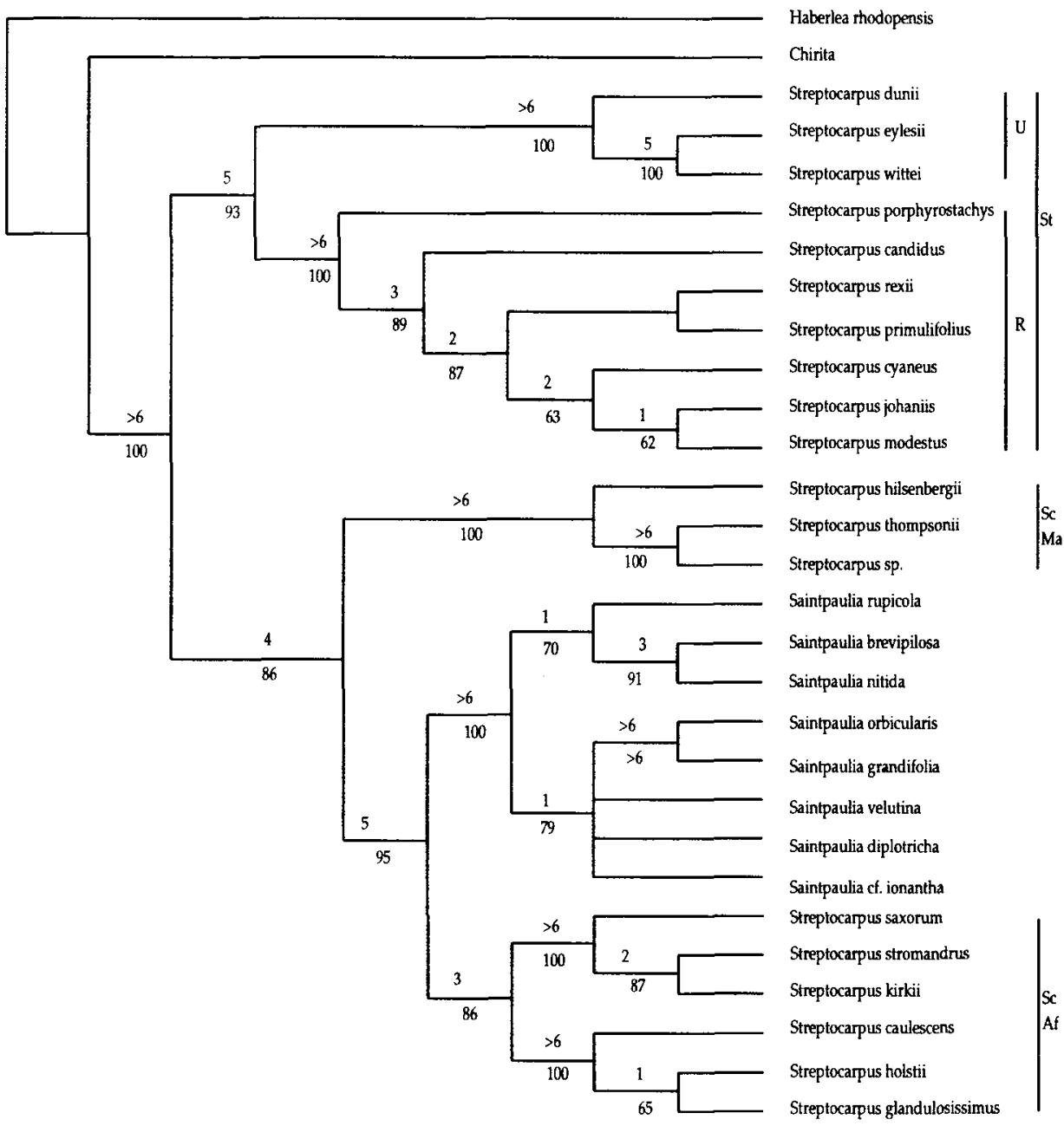

FIG. 2. Most-parsimonious tree of 419 steps $(C I=0.79, R I=0.90)$ based on nrDNA ITS sequences including aligned gaps. Redrawn from Möller \& Cronk (1997). Numbers above clades are decay values, numbers below clades are bootstrap values. Subgenera of Streptocarpus are indicated and abbreviated as follows: St, subg. Streptocarpus; Sc, subg. Streptocarpella; Ma, Madagascan species; Af, African species. Sections within subg. Streptocarpus are indicated and abbreviated as $\mathrm{U}$, unifoliate; $\mathrm{R}$, rosulate. 
some numbers; Saintpaulia and Streptocarpus subg. Streptocarpella are among the few species of the Gesneriaceae with $n=15$ chromosomes (Skog, 1984).

Despite different sampling strategies, the results presented here based on $n d h \mathrm{~F}$ sequence data (Fig. 1) and ITS sequence data (Fig. 2; Möller \& Cronk, 1997) are congruent. The major difference between the two analyses is the lower level of resolution obtained from the cpDNA (Fig. 1). Both the cpDNA and nrDNA indicated that Saintpaulia is closely related to Streptocarpus subg. Streptocarpella (Figs 1,2). The greater sampling from subg. Streptocarpella in the ITS study identifies two clades within this subgenus, one from mainland Africa and the other from Madagascar (Fig. 2; Möller \& Cronk, 1997). Both the $n d h \mathrm{~F}$ and ITS data indicate that subg. Streptocarpella (including Saintpaulia) is sister to the remainder of Streptocarpus (Figs 1,2). The greater resolution obtained from the ITS study indicates, as had been previously noted (Baldwin et al., 1995), that this region is better suited to resolve phylogenetic questions at the species and generic level.

A taxonomic revision of Streptocarpus and Saintpaulia is likely to be inevitable in order to reflect monophyletic genera, although no revision is recommended at this time. One possibility is to combine Saintpaulia into Streptocarpus subg. Streptocarpella; the other is to apply the name of Streptocarpella at the generic level to one of the clades and erect a new genus for the second (Fig. 2). This latter system is likely to be preferable in order to reflect the morphological distinctiveness of the species placed in Saintpaulia from Streptocarpus, and, since Saintpaulia is the most widely cultivated member of the family, would result in less confusion among horticulturists. Furthermore, the division of Streptocarpus subg. Streptocarpus into two sections, one the rosulate form, the other unifoliate, receives support from the ITS data (Fig. 2; Möller \& Cronk, 1997), although these sections were abandoned earlier on the basis of not being tenable by Hilliard \& Burtt (1971). To more fully resolve the nomenclatural issues within Streptocarpus, additional studies will be necessary to increase sampling among the species of this large and morphologically variable genus.

The major morphological shifts from Streptocarpus to Saintpaulia are the loss of the twisted fruit, the shortening of the corolla tube, and the loss of caulescence in Saintpaulia (although some species of Saintpaulia have a creeping stem rather than being rosulate and some Streptocarpus are rosulate), and the shift from nectar reward to pollen reward for pollinators (Hilliard \& Burtt, 1971; Möller \& Cronk, 1997). The loss of the twisted fruit may be the result of developmental constraints since the fruits of Saintpaulia are more globose in shape. The shift in fruit type is probably the result of selection pressures due to the habitat shift (most species of Saintpaulia occur on steep cliffs). The occurrence of twisted fruit, although long used to define Streptocarpus, is not unique to this genus. Other members of the Cyrtandroideae possess a twisted fruit, such as Boea, Ornithoboea, Paraboea (C.B. Clarke) Ridley, Rhabdothamnopsis Hemsl. and Trisepalum C.B. Clarke. Three of these genera (Boea, Paraboea and Ornithoboea) were included in an analysis of the tribal relationships of the Gesneriaceae along with two species of Streptocarpus (Smith et al., 1997a) and none showed any close affinity to Streptocarpus. A morphological analysis that 
did not include Boea or Paraboea did result in a close affinity of Streptocarpus and Ornithoboea but this relationship was only weakly supported (Smith, 1996). Therefore, the occurrence of the twisted fruit is likely to have several origins within the Cyrtandroideae.

The change in corolla shape and pollen reward probably reflects a shift in pollinator from Streptocarpus, albeit little is known regarding the natural pollinators of these plants (Hilliard \& Burtt, 1971). The change in habitat, for instance, from rock outcrops to steep cliffsides would probably result in a change in the pollen vector pool, and subsequent changes in the morphology of the flowers would be expected.

A recent analysis of pollen morphology among African Gesneriaceae indicated that the African genera Streptocarpus, Saintpaulia, Acanthonema Hook., Linnaeopsis Engler, Schizoboea (Fritsch) B.L. Burtt (Didymocarpus) and Trachystigma C.B. Clarke are likely to be a monophyletic group distinct from Asiatic taxa (Weigend \& Edwards, 1996). Since this present study has confirmed previous hypotheses on the close relationship of Saintpaulia and Streptocarpus subg. Streptocarpella, the inclusion of these additional genera in a molecular analysis may provide further support for the hypothesis generated from the pollen data. Unfortunately most of these genera are rarely collected and are currently not available for molecular analysis.

A comparison of the trees generated for these taxa based on different DNA sequences provides not only a chance to gain further confidence regarding the relationship of these genera (Donoghue, 1994), but also an opportunity to compare the utility of the two genomes. Sampling within Streptocarpus was much greater for the ITS region (Möller \& Cronk, 1997; Fig. 2) than it was for the $n d h$ F gene (Table 1, Fig. 1) and the sampling among the genera of the Cyrtandroideae was greater for the latter. Regardless, the results of the two analyses resolve the relationship of Saintpaulia to Streptocarpus consistently, indicating that the level of sampling was adequate for both studies in order to resolve this particular question. Further resolution among the different sections of Streptocarpus and among the species within these clades was obtained with ITS data that was not resolvable with the more conserved sequences of the $n d h \mathrm{~F}$ gene (Figs 1,2). Furthermore, the outgroups for both studies were different. Two genera from a related family (Buddlejaceae) were used for the cpDNA study (Fig. 1) and two genera within the Cyrtandroideae (Haberlea Friv. and Chirita) were used for the ITS study (Möller \& Cronk, 1997; Fig. 2). Based on a wider sampling of genera within the Cyrtandroideae (Smith et al., 1997a) Chirita is not closely related to the Streptocarpus/Saintpaulia clade. The congruence of the two analyses regarding the relationship of Streptocarpus and Saintpaulia indicates that the particular choice of outgroup was less important in resolving this question.

\section{ACKNOWLEDGEMENTS}

The authors wish to gratefully acknowledge the shared plant material provided by Jonathon Wendel, Laurence Skog and John Boggan. Funding for this project was 
provided through NSF grant DEB-9317775, a grant from the American Gloxinia and Gesneriad Society, and Boise State University Faculty Research Associates Program to J.F.S.

\section{REFERENCES}

BALDWIN, B. G., SANDERSON, M. J., PORTER, J. M., WOJCIECHOWSKI, M. F., CAMPBELL, C. S. \& DONOGHUE, M. J. (1995). The ITS region of nuclear ribosomal DNA: A valuable source of evidence of angiosperm phylogeny. Ann. Missouri Bot. Gard. 82: 247-277.

BREMER, K. (1988). The limits of amino acid sequence data in angiosperm phylogenetic reconstruction. Evolution 42: 795-803.

BREMER, K. (1994). Branch support and tree stability. Cladistics 10: 295-304.

BURTT, B. L. \& WIEHLER, H. (1995). Classification of the family Gesneriaceae. Gesneriana 1: 1-4.

CHASE, M. W., SOlTis, D. E., OlMSTEAD, R. G. et al. (1993). Phylogenetics of seed plants: An analysis of nucleotide sequences from the plastid gene $r b c \mathrm{~L}$. Ann. Missouri Bot. Gard. 80: 528-580.

CLARK, L. G., ZHANG, W. \& WENDEL, J. F. (1995). A phylogeny of the grass family (Poaceae) based on $n d h$ F Sequence Data. Syst. Bot. 20: 436-460.

DONOGHUE, M. J. (1994). Progress and prospects in reconstructing plant phylogeny. Ann. Missouri Bot. Gard. 81: 405-418.

Donoghue, M. J., OlmSteAd, R. G., SMiTh, J. F. \& PALMER, J. D. (1992). Phylogenetic relationships of Dipsacales based on $r b c \mathrm{~L}$ sequences. Ann. Missouri Bot. Gard. 79: 333-345.

FARRIS, S. J. (1970). Methods for computing Wagner trees. Syst. Zool. 19: 83-92.

FARRIS, S. J., KLUGE, A. G. \& ECKARDT, M. J. (1970). A numerical approach to phylogenetic systematics. Syst. Zool. 19: 172-191.

FELSENSTEIN, J. (1985). Confidence limits on phylogenies: an approach using the bootstrap. Evolution 39: 783-791.

HILliARD, O. M. \& BURTT, B. L. (1971). Streptocarpus, An African Plant Study. Pietermaritzburg, South Africa: University of Natal Press.

HILLIS, D. M. \& HUELSENBECK, J. P. (1992). Signal, noise, and reliability in molecular phylogenetic analyses. J. Heredity 83: 189-195.

HOLMQVIST, C. (1964). Some facts about the embryology of Gesneriaceae. Abstracts Tenth Int. Bot. Congress, p. 91. Edinburgh.

INNIS, M. A., MYAMBO, K. B., GELFAND, D. H. \& BROW, M. A. D. (1988). DNA sequencing and direct sequencing of polymerase chain reaction-amplified DNA. Proc. Natl. Acad. Sci. USA 85: 9436-9440.

MADDISON, D. R. (1991). The discovery and importance of multiple islands of mostparsimonious trees. Syst. Zool. 40: 315-328.

MÖLLER, M. \& CRONK, Q. C. B. (1997). Origin and relationships of Saintpaulia (Gesneriaceae) based on ribosomal DNA internal transcribed spacer (ITS) sequences. Amer. J. Bot. 84: 956-965.

OLMSTEAD, R. G. \& PALMER, J. D. (1994). Chloroplast DNA systematics: A review of methods and data analysis. Amer. J. Bot. 81: 1205-1224.

OLMSTEAD, R. G. \& SWEERE, J. A. (1994). Combining data in phylogenetic systematics: An empirical approach using three molecular data sets in the Solanaceae. Syst. Biol. 43: 467-481. 
OLMSTEAD, R. G. \& REEVES, P. A. (1995). Evidence for the polyphyly of the Scrophulariaceae based on chloroplast $r b c \mathbf{L}$ and $n d h \mathrm{~F}$ sequences. Ann. Missouri Bot. Gard. 82: 176-193.

OLMSTEAD, R. G., BREMER, B., SCOTT, K. M. \& PALMER, J. D. (1993). A parsimony analysis of the Asteridae sensu lato based on $r b c \mathrm{~L}$ sequences. Ann. Missouri Bot. Gard. 80: 700-722.

OLMSTEAD, R. G., MICHAELS, H. J., SCOTT, K. M. \& PALMER, J. D. (1992). Asteridae monophyly and major lineages of Asteridae inferred from $r b c \mathrm{~L}$ sequences. Ann. Missouri Bot. Gard. 79: 249-265.

SCOTLAND, R. W., SWEERE, J. A., REEVES, P. A. \& OlMSTEAD, R. G. (1995). Higher level systematics of Acanthaceae determined by chloroplast DNA sequences. Amer. J. Bot. 82: 266-275.

SKOG, L. E. (1984). A review of chromosome numbers in the Gesneriaceae. Selbyana 7 : 252-273.

SMITH, J. F. (1996). Tribal relationships within the Gesneriaceae: A cladistic analysis of morphological data. Syst. Bot. 21: 497-514.

SMITH, J. F., SYTSMA, K. J., SHOEMAKER, J. S. \& SMITH, R. L. (1992). A qualitative comparison of total cellular DNA extraction protocols. Phyt. Bull. 23: 2-9.

SMITH, J. F., WOLFRAM, J. C., BROWN, K. D., CARROLL, C. L. \& DENTON, D. S. (1997a). Tribal relationships in the Gesneriaceae: Evidence from DNA sequences of the chloroplast gene $n d h \mathrm{~F}$. Ann. Missouri Bot. Gard. 84: 50-66.

SMITH, J. F., BROWN, K. D., CARROLL, C. L. \& DENTON, D. S. (1997b). Familial placement of Cyrtandromoea, Titanotrichum, and Sanango: Three problematic genera of the Lamiales. Taxon 40: 65-74.

SUGIURA, M. (1989). The chloroplast chromosomes in land plants. Annu. Rev. Cell. Biol. 5: 51-70.

SUGIURA, M. (1992). The chloroplast genome. Plant Mol. Biol. 19: 149-168.

SWOFFORD, D. L. (1993). PAUP: Phylogenetic analysis using parsimony, version 3.1.1. Computer program distributed by the Illinois Natural History Survey, Champaign, Illinois.

SWOFFORD, D. L. \& MADDISON, W. P. (1987). Reconstructing ancestral character states under Wagner parsimony. Math. Biosci. 87: 199-229.

WANG, W. T., PAN, K. \& LI, Z. (1992). Keys to the Gesneriaceae of China. Edinb. J. Bot. 49: 5-74.

WEIGEND, M. \& EDWARDS, T. J. (1996). The palynology of Streptocarpus and the other African and Malagasy Gesneriaceae and its systematical implications. Bot. Jahrb. Syst. 118: 59-80. 